\title{
The Effect of Learning Strategy and Intelligence on the Student Learning Outcomes of STKIP Hamzar Lombok
}

\author{
Misrahudin, Robinson Situmorang, Hartati Muchtar
}

\begin{abstract}
The objectives of this research to study empirically the phenomena that occur related to learning approaches and interpersonal aptitude on the learning consequences of STKIP Hamzar students. The uasi-experimental method was used in this study with design treatment by level $2 \times 2$. - We have utilized questionnaires with multiple choice to derive learning outcomes and to measure the level of interpersonal intelligence of students. Learning outcomes learning instruments and interpersonal intelligence instruments were tested for validity with Biserial Correlation Points, and their reliability was tested by Kuder Richardson 20 (KR-20). The collected data was with a two-way ANOVA test. The results obtained based on hypothesis testing are: (1) Learning outcomes of student learning strategies taught with Rotating Trio Exchange (RTE) learning strategies are higher than the student learning outcomes taught with Direct learning strategies, (2) There is an communication effect between strategies learning and interpersonal intelligence on learning strategy learning outcomes, (3) learning outcomes of student learning strategies taught by the Rotating Trio Exchange (RTE) learning strategy are higher than the learning outcomes of pupils who are educated with Direct learning strategies, for pupils who have a level of interpersonal intelligence high, (4) Learning outcomes of learning strategies of students who are taught with Rotating Trio Exchange (RTE) learning strategies are lower than the learning effects of students who are taught with direct learning strategies, for students who have a low level of interpersonal intelligence
\end{abstract}

Keywords: Learning Strategy, Interpersonal Intelligence and Learning Outcomes

\section{INTRODUCTION}

Learning strategy courses are one of the subjects of expertise that must be mastered by students as prospective teachers. The course of learning strategy discusses material about understanding, goals and benefits of various strategies in learning activities, also concerning the paradigm shift in education, administration of learning, development of materials and evaluation of learning.

The learning activities carried out aim to obtain maximum learning outcomes, so to realize this goal is certainly supported by the selection and use of appropriate learning strategies. According to Andrianto et al. (2012), that To achieve these learning objectives, teachers must be good at

Revised Manuscript Received on September 22, 2019

Misrahudin, Post-Graduated Department of Educational Technology, Universitas Negeri Jakarta and Lecturer at STKIP Hamzar Lombok. iwa.syura@gmail.com

Robinson Situmorang, Lecturer at Universitas Negeri Jakarta

Hartati Muchtar, Professor at Universitas Terbuka Jakarta choosing the right learning strategy and creating an active classroom atmosphere to support the teaching and learning process and master the material taught (Andrianto et al., 2012). The reality in the field shows that some lecturers have not been right in choosing and implementing learning strategies, facilities and infrastructure that are not yet adequate, learning media that are not varied, the level of student readiness is not maximized, learning resources and materials are incomplete. This is a factor in the low student learning outcomes, as shown in the table below.

Table 1. Final Semester VI Results of PGSD S-1 Study Program Academic Year 2015/2016, 2016/2017 and $2017 / 2018$

ACADEMIC YEAR

No Code COURSE EYE 2014/ 2016/ 2017/

$2015 \quad 2017 \quad 2018$

\begin{tabular}{|c|c|c|c|c|c|}
\hline & \multirow{3}{*}{112307} & \multicolumn{4}{|l|}{ Mathematics } \\
\hline \multirow[t]{2}{*}{1} & & Education in Low & 2,75 & 2.80 & 2.80 \\
\hline & & Class & & & \\
\hline 2 & 112312 & $\begin{array}{l}\text { Science Education in } \\
\text { Low class }\end{array}$ & 2.76 & 2.68 & 2.85 \\
\hline & & Social Knowledge & & & \\
\hline 3 & 112321 & Fducation in Hioh & 285 & 300 & 328 \\
\hline
\end{tabular}

3112321 Education in High $\quad 2.85 \quad 3, .00 \quad 3.28$

Class

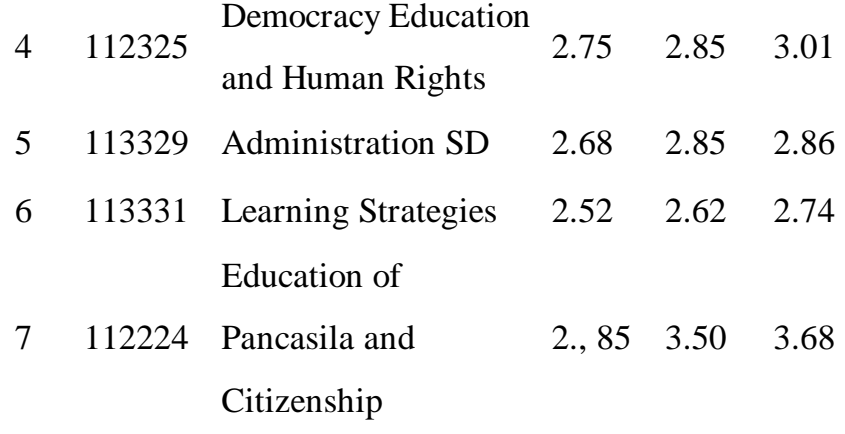

Source: Academic Section of STKIP Hamzar Lombok-NTB (2018)

Published By: Blue Eyes Intelligence Engineering 
Learning activities at all educational institutions aim to improve learning outcomes, change behaviour, improve student skills, so that lecturers are expected to choose the right learning strategies by learning materials, complementing various learning facilities and infrastructure. Grossen in Ewing, said "behavior-based learning activities that are linked directly to improving success in primary academic skills (Ewing, 2011)", so that each lecture is able to choose and use appropriate learning media based on learning material so that students are not saturated in participating in activities other expectations that can improve student learning outcomes are students are able to prepare mental and physical conditions so that the learning process runs smoothly. The campus can prepare learning resources in the form of literature by the lecture material so that students can prepare their cognitive abilities early before lecture activities are carried out. The efforts of lecturers in improving student learning outcomes in the course of learning strategy are to choose the right strategy so that it can increase student motivation, one of which is by using a strategy the lesson Rotating Trio Exchange. educated has not been able to demonstrate teaching skills either in the school environment or outside the school environment, such conditions arise due to low learning perseverance, causing low learning outcomes, as happened in the sixth-semester PGSD study program students. Showed that of the 60 students, 48 people had low learning outcomes as much as $80 \%$ and the remaining 12 people got above-standard scores of at least $20 \%$.

Another thing that cannot be denied to improve student learning outcomes is that lecturers should choose the right learning strategy to motivate students to be energetic, ly productive, innovative and fun in their learning so that they can improve student learning outcomes. Direct involvement of lecturers in the learning system can be linked to "highly organized lecturer-led learning that involves students for daily activities, collective assessment and independent practice" (Rizhaly et al., 2017).

Based on the background above, the researcher is interested in examining "the influence of learning strategies and interpersonal intelligence on learning outcomes in the learning strategies of the sixth-semester students of STKIP Hamzar."

\section{LITERATURE REVIEW}

\section{A. Learning Outcomes Learning Strategies}

Learning is an aspect related to how students learn, this is in accordance with what Gavin Raid said that earning is a science as well an arthe features of learning can be learned and can be utilized inside and outside school. Young students are often relegated to a less important role in education today (Reid, 2005).

Kimble \& Garmezy defined learning as the relatively permanent changes in attitude or behaviour that occur as a result of repeated experience"(Sims \& Sims, 2009). According to Slameto, learning is an attempt made by someone to obtain a change in new behaviour as a whole, as a result of his own experience in interacting with his
The fact that there are not a few alumni who are teacher

environment. (Slamento, 2006).

Likewise, with Mc Gaugh, Thompson, and Nelson, argues that learning is a relatively permanent change in behaviour produced by experience. (Thompson \& Nelson, 1997). Richey, Klein and Tracey suggested that learning is an everlasting change in one's skills and attitude (Richey, Klein, \& Tracey, 2011). This definition has three components, namely: (a) the duration of the change is long-term; (b) locus (part) change is the content and structure of knowledge in the memory or behaviour of students; (c) the cause of change is the experience and environment of the student. Conclusions from learning outcomes are changes in ability over a long period which is influenced by student internal factors (concerning physical and spiritual health) and external factors (concerning social environment, motivation and learning facilities) to produce changes in the level of thinking, attitudes and skills accumulated into goals.

\section{B. Learning Strategies}

According to Reigeluth, the learning strategies are integrated set of elements, such as specific ways the content ideas are sequenced, the use of overview and summaries, the use examples, the use of the practice, and the use of different strategies for motivating the student."(Reigeluth, 2013)

\section{1) The learning Rotating Trio Exchange}

The Rotating Trio Exchange strategy is one of the cooperative learning models (Silberman, 2009), used to motivate students to study with various models. Silberman's view of the learning strategy rotating Trio Exchange is: "Rotating Trio Exchange is participants are asked to discuss within trios a variety of questions that help them to get to know each other; learn about their attitudes, knowledge, and experience; and begin a discussion of the course content. (Herman Shoshana Silberman, 2009) This learning strategy Rotating Trio Exchange is a detailed procedure through which students discuss problems with their classmates. This exchange of opinions can be easily directed to the material to be taught in the classroom (Silberman, 2006).

Silberman in Oktaviana said: The Rotating Trio Exchange (RTE) is a learning strategy that enables students to carry out learning processes actively, dynamically, creatively, participate, cooperate and solve certain problems related to the subject matter. This strategy also develops an active learning environment by creating learners to physically move to share their thoughts and feelings openly and to gain feelings of joy and pride (Oktaviana, Suratno, and Aprilya, 2014).

The procedure for rotating trio exchange according to Malvin Silberman is:

- Lecturers split the class into several sections, and each section consists of three students.

- Students are divided into groups, each group consisting of three people (trio). The trio formations as a whole can be round or square. (Kurnianto, Kuswadi, and Lestari, 2016) 
- Give each trio the same questions and with easy levels to be discussed with the group members.

- Give numbering to each trio, which is from 0.1 and 2 . With the condition that 0 stays in his seat, one rotates clockwise once; two rotates clockwise differently twice to provide clear information about various issues discussed at the time of the trial.

- Students will exchange opinions based on the same questions given by the lecturer to all trio groups that will be completed according to the difficulty level of the questions.

- The lecturer rotates three groups many times as many questions as there are available times. (Siberman, 2011)

\section{2) Direct Learning Strategy}

Roy Killen in Sanjaya (2008) calls the direct learning strategy with the name (direct instruction) because, in this strategy, lecture material is delivered directly by the lecturer. Students are allowed to find material, as a comparison because lecture material has been provided previously by the lecturer. Maria, et al. Emphasized: "Direct Instruction (Direct Instruction) is one of the teaching models specifically designed to develop student learning about procedural knowledge and declarative knowledge that is well structured and can be studied step by step". (Mariati, Raga, and Pudjawan, 2014)

Ewing emphasized that direct and explicit step-by-step approach is more beneficial for the student due to the restrictions of working memory. The teacher's responsibility is to ensure the student's attention during a lecture session with any available methods (Ewing, 2011)

\section{Intelligence}

Interpersonal According to Yaumi that: "Interpersonal intelligence as the ability to perceive and distinguish moods, intentions, motivations, and desires of others, and ability to respond appropriately to the mood, temperament, motivation and desires of others". (Yaumi, 2012)

According to Gardner himself that interpersonal intelligence is needed by individuals to find out their moods in the surrounding environment when interacting with others. In his book, it is emphasized that the interpersonal intelligence of the baby to differentiate among individuals in his surrounding and to detect their various moods (Gadner, 2004). According to Anderson, this interpersonal intelligence consists of three dimensions, of which all three have complementary entities. Social sensitivity, social insight and social communication are the three dimensions of Anderson's interpersonal intelligence -(Wahyudi, 2011).

According to Hoer who saw the characteristics of interpersonal intelligence are: " Enjoys cooperative games, demonstrates empathy, others, has lots of friends, is admired by peers, and displays leadership skills, prefers group problem solving, can mediate conflicts, understand and reconcile stereotypes and prejudices. " (Hoer, Bogeman and Wallach, 2010) The point is that intelligence between personal must have the characteristics of feeling like someone else, being empathetic, lots of friends, liked by many people, like leadership skills, likes group problem solving, can mediate conflicts, and eliminate various assumptions. According to Baum, there are three keys to interpersonal intelligence, namely: " sensitivity, beliefs, moods, and intentions of other people; the use of understanding to work effectively with other; includes capitalizing on interpersonal skills in the pursuit of one's ends. (Baum, Viens, and Slatin, 2005) The key to interpersonal intelligence is sensitivity to meetings, using understanding to work effectively with others and utilizing the ability of cooperation with others in achieving goals.

\section{METHODOLOGY/MATERIALS}

This study uses a quasi-experimental method with design treatmentby $2 \times 2$. Multiple choice tests were employed in this research -to find the learning effects and the level of interpersonal intelligence of students. Learning outcomes instruments of learning strategy subjects and student interpersonal intelligence were tested for validity with Biserial Correlation Points and their reliability was tested by Kuder Richardson 20 (KR-20). The results of testing the results of the instrument obtained 40 valid questions from 45 questions with a very high level of reliability. The results of testing interpersonal intelligence instruments obtained 58 valid questions from 58 questions with very high levels of reliability. Hypothesis testing and test requirements analysis were techniques used for data analysis in this study. Test requirements analysis consists of normality test using Lilliefors test and homogeneity test using test Bartlett. A two-way Anava test was utilized to analyze the collected data. NOVA.

Based on the study of the theory and framework of the above, the hypothesis proposed in this study are as follows:

- Learning outcomes among students that learned by using learning strategies Exchange Rotating Trio higher than direct learning strategies in the course of learning strategies

- There is an effect of interaction among learning strategies and interpersonal intelligence on learning outcomes in learning strategy courses at STKIP Hamzar.

- Learning outcomes between students who are taught with the Rotating Trio Exchange are higher than those in direct learning strategies that have high interpersonal intelligence in learning strategy courses that have low interpersonal intelligence in learning strategy courses.

Learning outcomes between students who were taught with the Rotating Triorio Exchange were lower than those who were taught using the direct learning strategy

\section{RESULTS AND FINDINGS}

\section{A. Data Exposure}

Based on the research design treatment by level, the $2 \times 2$ data in this study can be presented into eight groups, namely: a). Student groups were taught using the learning strategy rotating trio exchange $b$ ).

Blue Eyes Intelligence Engineering

\& Sciences Publication 
Student groups were taught with direct learning strategies, c). Sections of students who have a high level of interpersonal intelligence, d). Group of students who have a low level of interpersonal intelligence, e). Student groups were taught by learning strategies rotating trio exchange that have high interpersonal intelligence, $f$ ). The student group learned with the learning strategy rotating trio exchange that has low interpersonal intelligence, g). The student group was taught with direct learning strategies which have high interpersonal intelligence, and h). The student group was taught with direct learning strategies which have low interpersonal intelligence.

The description of learning outcomes in the course of learning strategies is summarized in the table below, namely:

Table 2: Description of learning outcomes data for STKIP Hamzar Lombok student learning strategy courses

Learning Strategy Amount of

\section{Interpersona Rotating Trio Direct}

1 Intelligence Exchange

$\mathbf{A}_{1}$

$\mathbf{A}_{2}$

\begin{tabular}{ccccccc}
\hline Height (B1) & $\mathrm{n}_{\mathrm{A} 1 \mathrm{~B} 1}$ & 10 & $\mathrm{n}_{\mathrm{A} 2 \mathrm{~B} 1}$ & 10 & $\mathrm{n}_{\mathrm{B} 1}$ & 20 \\
& $\Sigma \mathrm{x}$ & 341 & $\Sigma \mathrm{x}$ & 284 & $\Sigma \mathrm{x}$ & 625 \\
& $\Sigma \mathrm{x}^{2}$ & 11837 & $\Sigma \mathrm{x}^{2}$ & 8198 & $\Sigma \mathrm{x}^{2}$ & 20035 \\
& $\mathrm{~s}^{2}$ & 20.89 & $\mathrm{~s}^{2}$ & 13.24 & $\mathrm{~s}^{2}$ & 25.19 \\
& & 34.10 & & 28.40 & & 31.25 \\
Low (B2) & $\mathrm{n}_{\mathrm{A} 1 \mathrm{~B} 2}$ & 10 & $\mathrm{n}_{\mathrm{A} 2 \mathrm{~B} 2}$ & 10 & $\mathrm{n}_{\mathrm{B} 2}$ & 20 \\
& $\Sigma \mathrm{x}$ & 281 & $\Sigma \mathrm{x}$ & 288 & $\Sigma \mathrm{x}$ & 569 \\
& $\Sigma \mathrm{x}^{2}$ & 8059 & $\Sigma \mathrm{x}^{2}$ & 8282 & $\Sigma \mathrm{x}^{2}$ & 16541 \\
& $\mathrm{~s}^{2}$ & 16,29 & $\mathrm{~s}^{2}$ & 18,76 & $\mathrm{~s}^{2}$ & 17,65 \\
& & 28.10 & & 28.80 & & 28,45 \\
Number of & $\mathrm{n}_{\mathrm{A} 1}$ & 20 & $\mathrm{n}_{\mathrm{A} 2}$ & 20 & $\mathrm{n}_{\mathrm{B}}$ & 40 \\
& $\sum \mathrm{x}$ & 622 & $\sum \mathrm{x}$ & 572 & $\sum \mathrm{x}$ & 1194 \\
& $\sum \mathrm{x}^{2}$ & 19896 & $\sum \mathrm{x}^{2}$ & 16680 & $\sum \mathrm{x}^{2}$ & 36576 \\
& $\mathrm{~s}^{2}$ & 27,59 & $\mathrm{~s}^{2}$ & 16.04 & $\mathrm{~s}^{2}$ & 17.30 \\
& & 31.10 & & 28.60 & & 29,85
\end{tabular}

1) Learning Outcomes Data on Student Learning Strategies Using the learning Strategy Rotating Trio Exchange

Learning outcomes of students' learning strategy courses using the learning strategy are rotating trio exchange shown in table 2.1 with 40 multiple choice questions, the highest score $=39$, the min value $=20$, the maximum value of $X$ max: 39 ; the average value of $\mathrm{X}=31.25$; and standard intersections $=25.19$.

Learning outcomes of students' learning strategies courses that use the strategy rotating trio exchange appears in the distribution. It can be seen that the average data of 31.55 lies in intervals $32-35$. Thus there are five students or $25 \%$ of the number of students who get learning outcomes around the average, and there are four people or $25 \%$ of students who get learning outcomes below the average, and there are 11 students or $50 \%$ who get above average learning outcomes.

2) Learning Outcomes Data on Student Learning Strategies Using Direct Learning Strategies

Student learning outcomes in learning strategy courses that use direct learning strategies (in table 2.1) after analysis of learning outcomes data obtained maximum scores $=34$ with the total number of values $\sum X=572$; the value of $X$ min $=20$; the average value of $\mathrm{X}=28.60$ standard intersection value $=16.04$.

Student learning outcomes in learning strategy courses that use direct learning strategies. It can be seen that the average data of 28.60 lies in the interval 28-31. Thus there are seven students or $30 \%$ of the number of students who get learning outcomes around the average, and there are nine people or $45 \%$ of students who get learning outcomes below the average, and there are four students or $25 \%$ who get above average learning outcomes.

3) Learning Outcomes Data on Student Learning Strategies that Have High Interpersonal Intelligence

Student learning outcomes in learning strategy courses that have high interpersonal intelligence (table 2.1) the highest average score is obtained $=39$; total value $\sum X=281$; lowest score $=22$; the average value of $X=31.10$, and the standard intersection $=27.59$.

The tendency of learning outcomes in student learning strategies courses that have high interpersonal intelligence. It can be seen that the average data is 31.10 located at intervals $31-33$. Thus there are seven students or $35 \%$ of the number of students who get learning outcomes around the average, and there are seven people or $35 \%$ of students who get learning outcomes below the average, and there are six students or $30 \%$ who get above average learning outcomes.

4) Learning Outcomes Data on Student Learning Strategies that Have Low Interpersonal Intelligence

Student learning outcomes in learning strategy courses that have low interpersonal intelligence (in table 2.1) the highest average score is obtained $=36$; total value $\sum X=569$; lowest score $=20$; the average value of $\mathrm{X}=28.45$ and standard intersection $=17.65$.

The tendency of learning outcomes in student learning strategies courses that have low interpersonal intelligence. It can be seen that the average data of 28.80 lies in the interval 29-31. Thus there are five students or $25 \%$ of the number of students who get learning outcomes around the average, and there are ten students or $50 \%$ of students who get learning outcomes below the average, and there are five students or $25 \%$ who get above average learning outcomes. 
5) Learning Outcomes Data on Student Learning Strategies that Have High Interpersonal Intelligence Are Learned by Using the strategy Rotating Trio Exchange

Learning outcomes data of students' learning strategies that have high interpersonal intelligence are learned using the strategy rotating trio exchange (in table 2.1) obtained the highest score $=39$ total value $\sum X=341$; lowest score $=24$; the average value of $\mathrm{X}=31.10$ and standard intersection $=$ 20.89.

The tendency of learning outcomes in student learning strategies that have high interpersonal intelligence is learned by using the strategy rotating trio exchange. It can be seen that the average learning outcomes obtained data amounted to 31.10 , which was learned using the learning strategy rotating trio exchange that has a high level of interpersonal intelligence, located at intervals 32-35. Thus there are four students or $20 \%$ of the number of students who get learning outcomes around the average, and there are two people or $10 \%$ of students who get learning outcomes below the average, and there are four students or $20 \%$ who get learning outcomes above the average.

Learning Outcomes Data on Student Learning Strategies that Have High Interpersonal Intelligence Are Learned by Using Direct Learning Strategies

Learning outcomes data of students' learning strategies that have high interpersonal intelligence are learned using direct learning strategies (in table 2.1) obtained the highest score $=36$; total value $\sum X=284$; lowest score $=22$; the average value of $\mathrm{X}=28.40$ and standard intersection = 13.24 .

The tendency of learning outcomes of students' learning strategies courses that have high interpersonal intelligence is learned by using direct learning strategies. It can be seen that the average learning outcomes obtained data amounted to 28.40, which was learned using direct learning strategies that have a high level of interpersonal intelligence, located at intervals of 28-30. Thus there are two students or $10 \%$ of the number of students who get learning outcomes around the average, and there are four people or $20 \%$ of students who get learning outcomes below the average, and there are four students or $20 \%$ who get above average learning outcomes.

6) Learning Outcomes Data on Student Learning Strategies that Have Low Interpersonal Intelligence Are Learned by Using the strategy Rotating Trio Exchange

Learning outcomes data of students' learning strategies that have low interpersonal intelligence are learned using the strategy rotating trio exchange (in table 2.1) obtained the highest score $=36$; total value $\sum X=281$; lowest score $=22$; the average value of $\mathrm{X}=28.10$ and standard intersection $=$ 16.29.

The trend of learning outcomes of students' learning strategies courses that have low interpersonal intelligence is learned by using the strategy rotating trio exchange. It can be seen that the average learning outcomes obtained data amounted to 28.10, which was learned using the learning strategy rotating trio exchange that has a low level of interpersonal intelligence, located at intervals 28-31. Thus there are four students or $20 \%$ of the number of students who get learning outcomes around the average, and there are four people or $20 \%$ of students who get learning outcomes below the average, and there are two students or $10 \%$ who get above average learning outcomes.

7) Learning Outcomes Data Subjects Learning Strategies Students Who Have Low Interpersonal Intelligence Are Learned by Using Direct Learning Strategies

Learning outcomes data of student learning strategies students who have low interpersonal intelligence are taught by using direct learning strategies (in table 2.1) obtained the highest score $=34$; total value $\sum X=288$; lowest score $=20$; the average value of $\mathrm{X}=18.76$, and the standard intersection $=28.80$.

The tendency of learning outcomes in student learning strategy courses that have low interpersonal intelligence is learned by using direct learning strategies. It can be seen that the average learning outcomes obtained by data are 28.80 , which is learned by using direct learning strategies that have a low level of interpersonal intelligence, located at intervals of 29-31. Thus there are four students or $20 \%$ of the number of students who get learning outcomes around the average, and there are theree people or $15 \%$ of students who get learning outcomes below the average, and there are theree students or $15 \%$ who get above average learning outcomes.

\section{B. Discussion of Research Results}

There are differences in learning outcomes between students who are taught using the learning strategy Rotating Trio Exchange with a student who is using the Direct learning strategy in the learning strategy course.

Based on two-way ANOVA analysis data (complete randomized design) (found in table 2.2) shows that testing of learning outcomes using learning strategies with a significance level of $5 \%$ or $\alpha=0.05$, obtained Fcount $=$ 3.252 , with Ftable $=2.634$, then the value of Fcount $>$ Ftable then rejects Ho thus it can be said that the learning outcomes of students who are taught with a strategy rotating trio exchange are higher than the learning outcomes of students who are taught with direct learning strategies.

Table 3. Data analysis Two-lane variant (Complete Random Design)

\begin{tabular}{llllll}
\hline $\begin{array}{lllll}\text { Variance } \\
\text { Source }\end{array}$ & JK & DB & RJK & Fhitung & $\begin{array}{l}\text { Ftabel } \\
\boldsymbol{\alpha}= \\
\mathbf{0 : 0 5}\end{array}$ \\
\hline Interagency A & 62.50 & 1 & 62.50 & 3.252 & 2.634 \\
Antar B & 78.40 & 1 & 78.40 & 4.080 & 2.634 \\
AxB & 102.40 & 1 & 102.40 & 5,329 & 2,634 \\
interaction & & & & & \\
In & 691.80 & 36 & 19,22 & & \\
\multicolumn{1}{c}{9035.1} & 3 & & &
\end{tabular}

The conclusion of the first hypothesis is based on the two-way ANOVA test that the student learning outcomes are learned using a higher rotating trio exchange learning strategy compared to the direct learning strategy. It can be said that the learning strategy 
is a rotating trio exchange more effective than straight learning.

There is an interaction effect between learning strategies and interpersonal intelligence on learning outcomes in the course of learning strategies at STKIP Hamzar.

The second statistical hypothesis about the interaction of learning strategies and interpersonal intelligence on learning outcomes in learning strategy subjects is:

$\mathrm{HO}: \mathrm{A} \times \mathrm{B}=0$

$\mathrm{H} 1: \mathrm{A} \times \mathrm{B} \neq 0$

Hypothesis:

$\mathrm{H} 0$ : There is no influence of interaction between learning strategies and interpersonal intelligence on learning outcomes

$\mathrm{H} 1$ : There is an influence of interaction between learning strategies and interpersonal intelligence on learning outcomes.

By using the test criteria:

- If the value of Fcount <Ftbel then accept HO

- If the value of Fcount $>$ Ftable then reject H0.

The calculation results using two-way ANOVA (table 4.14). The results of testing the interaction between the use of learning strategies and interpersonal intelligence on learning outcomes obtained Fcount $=3,252$ with a value of Ftable $=2.634$. This means that the value of Fcount $>$ Ftable, then reject $\mathrm{H} 0$. This means that there is an interaction between learning strategies and interpersonal intelligence on the learning outcomes of the learning strategies of STKIP Hamzar Lombok students.

The results of testing the hypothesis about the statement of the interaction between learning strategies with interpersonal intelligence on learning outcomes of the learning strategies of STKIP Hamzar Lombok students can be seen in Figure 1

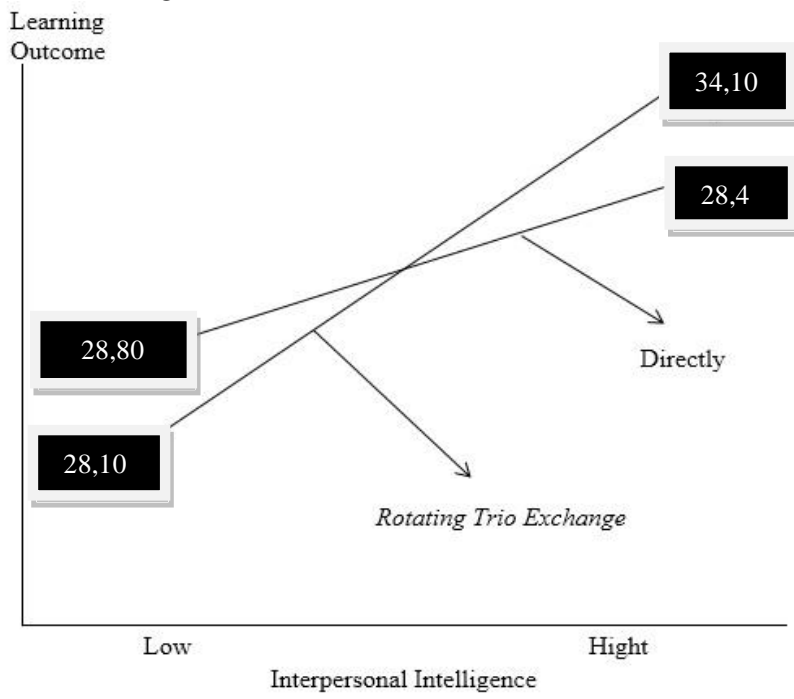

Charts: 1: Images of Interpersonal Interaction Learning and Interaction strategies on learning outcomes of STKIP Hamzar Lombok students.

Testing the interaction between the learning strategy rotating trio exchange and interpersonal intelligence on the learning outcomes of the learning strategy course with ANAVA is two-was very significant.

Figure 1 shows significant results, meaning that there is an interaction between learning strategies and interpersonal intelligence on learning outcomes of learning strategy subjects in STKIP Hamzar Lombok students. Is punctuated by a further test using testDunnet specified in Table 4. below:

Table 4: The summary analysis further test using Dunnet

\begin{tabular}{lllll}
\hline Group & $\mathbf{t}$ & Tt & $\begin{array}{l}\text { Hypothesis } \\
(\text { H1 })\end{array}$ & $\begin{array}{l}\text { Test } \\
\text { Decision }\end{array}$ \\
\hline A1B1 - A2B1 & 2.908 & 2.228 & A1B1> A2B1 & Ho rejected \\
& -0.35 & & & \\
A1B2 - A2B2 & 7 & -2.228 & A1B2< A2B2 & Ho rejected \\
& & & &
\end{tabular}

There are differences in learning outcomes between students who are taught with the Rotating Trio Exchange compared to students who use direct learning strategies in students who have high interpersonal intelligence

The test results above obtained the results of the RTE learning strategy with high interpersonal intelligence better than the direct learning strategy with high interpersonal intelligence, with a significance level of $5 \%$ or $\alpha=0.05$, obtained by the value of arithmetic $=3.252$ with the value of table $=2.634$ means that $>$ table, then to H0, meaning the learning outcomes of learning strategy subjects in STKIP Hamzar students who were taught using the learning strategy rotating trio exchange with high interpersonal intelligence was higher than the student learning outcomes taught with direct learning strategies with high interpersonal intelligence.

There are differences in learning outcomes between students who are taught with the Rotating Trio Exchange with students who are taught using direct learning strategies for students who have low interpersonal intelligence

The Fourth Hypothesis:

$$
\begin{aligned}
& \mathrm{H} 0=\mu \mathrm{A} 1 \mathrm{~B} 2=\mu \mathrm{A} 2 \mathrm{~B} 2 \\
& \mathrm{H} 1=\mu \mathrm{A} 1 \mathrm{~B} 2<\mu \mathrm{A} 2 \mathrm{~B} 2
\end{aligned}
$$

H0: Student learning outcomes learned using the learning strategy rotating trio exchange that has low interpersonal intelligence are not lower than those taught with direct learning strategies.

H1: Student learning outcomes learned by using a learning strategy rotating trio exchange that has low interpersonal intelligence is lower than what is taught by direct learning strategies.

Testing the learning outcomes data using the Tuckey test on the results of learning rotating trio exchange with low interpersonal intelligence is not lower than the direct learning strategy with low interpersonal intelligence, this is evidenced by using a significance level of $5 \%$ or $\alpha=0.005$, obtained count $=-0.357$ with table $=-2.228$ meanst $<$ table then rejected $\mathrm{H} 0$, this means that the results of student learning which has low interpersonal intelligence be taught by using a strategy rotating trio exchange does lower when compared with the direct learning strategies. 


\section{Conclusion}

Based on the results of the research and discussion that has been described, conclusions can be drawn as follows:

- Student learning outcomes in learning strategy courses that use learning strategies rotating trio exchange (RTE)are higher compared to learning outcomes that use direct learning strategies.

- There is an interaction between the use of learning strategies and the level of interpersonal intelligence on student learning outcomes in the course of learning strategies.

- Learning outcomes of learning strategy courses that were taught by learning strategies rotating trio exchange were higher than those of students who were taught with direct learning strategies, for students who had high interpersonal intelligence.

- Student learning outcomes in learning strategy courses, having a low level of interpersonal intelligence learned by the learning strategy rotating trio exchange lower than the learning outcomes of students are higher with direct learning strategies, because Ho was rejected in the study.

\section{ACKNOWLEDGEMENTS:}

This research work is supported by STKIP Hamzar Lombok.

\section{REFERENCES}

[1] Andrianto, Raharjo, Qomariah, "Implementation of Active Learning with the Rotating Trio Exchange Strategy on the material of the Respiratory System"'”' ejurnal Unesa, BioEdu Vol. 1/No.3/Desember 2012, h.21

[2] Bronwyn Ewing, "Direct Instruction in Mathematics: Issues For Schools With High Indigenous Enrolments: A Literature Review Direct Instruction In Mathematics: Issues For Schools With High Indigenous Enrolments: A Literature Review" Australian Journal of Teacher Education 2011: Vol. 36: Iss. 5, Article 6

[3] Dedy Wahyudi, Social Studies Learning Based on Interpersonal Intelligence, Interpersonal and Existential,, Jurnal UPI Edisi Khusus, No. 1 Agustus 2011, h.37

[4] Dorothy Herman Shoshana Silberman, Active Training (57 strategis to enlivenyour class (Publish by: Torah Aura Prodaction, 2009) h. 64

[5] Desak Putu Mariati,I Gede Raga, Ketut Pudjawan, The Application of direct instruction models assisted with the media of paper folding to improve children's fine motor skills, shanti kumara iii sempidi. e-Journal PG-PAUD Universitas Pendidikan Ganesha Jurusan Pendidikan Guru Pendidikan Anak Usia Dini (Volume 2 No 1 Tahun 2014). h. 4.

[6] Friska Oktaviana W.C., Suratno, Sulifah Aprilya H, (Implementation of Eksperiment Method and Rotating Trio Exchange Strategy in Improving Activity and Learning Result of Biology Science (Class VIII SMP Negeri 1 Jelbuk Jember Student Academic Year 2014/2015), jurnal edukasi unej 2015, ii (1): 5-10, h.6

[7] Gavin Reid, Learning Styles and Inclusion, (P.C.P; 2005), h. 3

[8] James L. McGaugh, Richard F. Thompson, Thomas O. Nelson, Psychology I: An Experimental Approach, (California: Albion Publishing Company: 1977), hh. 198,

[9] Howard Gadner, Frames of Mind the Theory of multiple Inelligences, (New york, Basic Books, 2004) hal, 239

[10] Melvin, L. Silberman, Active Learning, (Bandung: Nuansa, 2006), h. 103

[11] Malvin Silberman, 101 Ways to make training active (57 metodes to enlivenyour class (Publish by: Pfeiffer Prodaction, 2011) h. 92.

[12] Muhammad yaumi, Multiple intelligences based learning, (Jakarta, Dian Rakyat,2012), hal 21-22

[13] Rizhaly B. Maandig, Laila S. Lomibao, Charita A. Luna, "Structured Content Reading Instruction vs. Direct Instruction: Their Implication on Students' Achievement, Reading Comprehension and Critical Thinking in Mathematics" American Journal of Educational Research. 2017, 5(5), 574-578. DOI: 10.12691/education-5-5-16, Published online: June 07, 2017. h. 1

[14] Ronald R. Sims and Serbrenia J. Sims, The Importance of Learning Styles: Understanding The Implications for Learning, (Westport: Greenwood Press, 2009), h.2.

[15] Rita C. Richey, James D. Klein, Monica W. Tracey, The Instructional Design Knowledge Base: Theory, Research, and Practice. (New York: Routledge, 2011), h.61.

[16] Reigeluth, Charles M, Instructional Design Theories and Models, An Overview of Their Current Status (London: Lawrence Erlbaum Associates, 2013)., h.31.

[17] Malvin L Silberman, Active Learning, (Bandung: Nuansa, 2006), 103.

[18] Slameto, Learning and the Affecting Factors (Jakarta: Rineka Cipta, 2006), h. 2

[19] Septian Kurnianto1), Kuswadi2), Lies Lestari3). "“Increased Understanding of the Concept of Summation and Reduction of Fraction Numbers Through Cooperative Model Type Rotating Exchange (RTE)"'” Jurnal PGSD FKIP Universitas Sebelas Maret, Jalan Slamet Riyadi 449 Surakarta 57126. h.2 diunggah pada tanggal 2 November 2016

[20] Thomas R Hoer, Sally Bogeman dan Christina Wallach, Celebeiting Every Leaner, Activities and Metodees for Creating a Multiple Intelligences Classroom, (San Fransisco, Jassey Bass Published, 2010), h.8

[21] Susan Baum, Julie Viens, dan Barbara Slatin, Multiple Intelligence In The Elementary Classroom A Teacher's Tolkit, (New York; Teacher's College Press, 2005), h.17

[22] Wina Sanjaya, Learning Strategy Oriented to Educational Process Standards (Jakarta: Kencana Prenada Media, 2008), h. 179

\section{AUTHORS PROFILE}

Misrahudin is a Post-Graduate student in Department of Educational Technology, Universitas Negeri Jakarta and Lecturer at STKIP Hamzar.

Robinson Situmorang is a Lecturer attached to Universitas Negeri Jakarta. His area of research is Educational Technology. He has written articles and presented several papers in international and national conferences.

Hartati Muchtar is a Professor in Educational Technology, Postgraduate Program, Universitas Negeri Jakarta (Jakarta State University). Permanent and daily lecturers teach and guide the Thesis and Dissertation of postgraduate students in the Educational Technology Study Program, Jakarta State University. 